\title{
Penanganan Budidaya Kentang (Solanum tuberosum L.) di Bandung, Jawa Barat
}

\section{Handling of Potato Cultivation (Solanum tuberosum L.) at Bandung, West Java}

\section{Gina Rahma Utami, Megayani Sri Rahayu*, Asep Setiawan}

Departemen Agronomi dan Hortikultura, Fakultas Pertanian, Institut Pertanian Bogor (Bogor Agricultural University), Jl. Meranti, Kampus IPB Darmaga, Bogor 16680, Indonesia

Telp.\&Faks.62-251-8629353 e-mail agronipb@indo.net.id

*Penulis untuk korespondensi: megasetiawan23@yahoo.com

Disetujui 7 Januari 2015 /Published online 15 Januari 2015

\begin{abstract}
This research has been done to learn management aspect of potato cultivation. This research was implanted at Kabupaten Bandung, West Java on 14 February until 14 June 2011. The particular aspect that has been observed is influence of early ridging against the growth of potato plant. The treatment that has been done is height of ridging on $10 \mathrm{~cm}, 15 \mathrm{~cm}, 20 \mathrm{~cm}$ and observed variable was percentage of seedling growth, height of plant, number of stolons per stem and tuber weight at harvest. Analysis result has shown that the treatment height of ridging has significantly influence on percentage of seedling growth on 21 st day after planting and has very significantly influence on height of plant on 28th day after planting.
\end{abstract}

Keywords : cultivation, potato, ridging

\section{ABSTRAK}

Penelitian ini dilakukan untuk mempelajari aspek pengelolaan budi daya komoditas kentang. Penelitian dilaksanakan di Kabupaten Bandung, Jawa Barat pada tanggal 14 Februari sampai dengan 14 Juni 2011. Aspek khusus yang diamati adalah pengaruh pembumbunan awal terhadap pertumbuhan tanaman kentang. Perlakuan yang dilakukan adalah ketinggian pembumbunan pada $10 \mathrm{~cm}, 15 \mathrm{~cm}, 20 \mathrm{~cm}$ dan variabel yang diamati adalah persentase pertumbuhan bibit, tinggi tanaman, jumlah stolon per batang dan bobot umbi saat panen. Hasil analisis menunjukkan bahwa tinggi perlakuan pembumbunan berpengaruh nyata terhadap persentase tumbuh bibit pada 21 hari setelah tanam dan berpengaruh sangat nyata terhadap tinggi tanaman pada 28 hari setelah tanam.

Kata kunci: budi daya, kentang, pembumbunan 


\section{PENDAHULUAN}

Sayuran merupakan istilah yang biasanya digunakan untuk merujuk pada tunas, daun, buah, dan akar tanaman yang lunak dan dapat dimakan secara utuh atau sebagian, mentah atau dimasak, sebagai pelengkap pada makanan berpati atau daging. Sayuran biasanya dipanen dalam keadaan segar dan kandungan airnya tinggi (Williams et al., 1993).

Berdasarkan perbedaan tanggapan terhadap suhu untuk pertumbuhan, sayuran dapat diklasifikasikan menjadi sayuran iklim panas dan iklim dingin. Kentang merupakan salah satu contoh sayuran yang termasuk ke dalam kategori sayuran iklim dingin karena selama masa pertumbuhan dan perkembangannya memerlukan suhu $10-18{ }^{\circ} \mathrm{C}$. Tanaman ini berasal dari wilayah Pegunungan Andes di Peru dan Bolivia, kemudian menyebar ke Cili, Kolumbia, Ekuador, Spanyol, dan seluruh benua Eropa (Rubatzky dan Yamaguchi, 1998). Kentang yang masuk Indonesia adalah kentang yang berasal dari Amerika yaitu kentang Eigenheimer. Kentang tersebut ditemukan di sekitar Cimahi, Bandung pada tahun 1794, kemudian disebarkan di daerah Karo, Aceh, Padang, Bengkulu, Minahasa, Bali, Seram dan Timor (Setiadi dan Nurulhuda, 2008).

Kentang (Solanum tuberosum L.) merupakan tanaman sayuran semusim, berumur 90-180 hari, dan termasuk tipe tanaman semak. Kentang menyukai tanah yang diolah baik dan gembur. Kentang lebih cocok ditanam pada daerah dataran tinggi atau pegunungan dengan ketinggian lebih dari $700 \mathrm{~m}$ dpl (Samadi, 2007).

Prospek serapan untuk konsumsi dan permintaan pasar terhadap komoditas kentang dapat dilihat dari ju mlah penduduk dan peningkatannya dari tahun ke tahun, karena kebutuhan untuk konsumsi pangan meningkat sejalan dengan pertumbuhan penduduk (Samadi, 2007). Produksi kentang di Indonesia cenderung mengalami peningkatan dari tahun 2001 sebesar 831140 ton menjadi 1176304 ton pada tahun 2009. Produksi tahun 2001 diperoleh dari lahan seluas 55971 ha dengan produktivitas sebesar 14.85 ton $\mathrm{ha}^{-1}$, sedangkan tahun 2009 diperoleh dari lahan seluas 71238 ha yang tersebar di seluruh Indonesia dengan produktivitas sebesar 16.51 ton $\mathrm{ha}^{-1}$ (BPS, 2010).

Permasalahan yang sering dihadapi dalam produksi kentang nasional adalah hasil yang berfluktuatif. Salah satu penyebabnya terjadi saat kegiatan budidaya dilaksanakan yaitu perlakuan pembumbunan. Pembumbunan sangat berpengaruh terhadap hasil yang akan didapatkan. Keadaan bumbunan yang baik dan ideal sangat diharapkan yaitu bumbunan yang tidak terlalu pendek ataupun terlalu tinggi (Setiadi dan Nurulhuda, 2008). Bumbunan yang terlalu pendek akan membuat umbi muncul ke permukaan dan terkena sinar matahari sehingga umbi berwarna hijau, sedangkan bumbunan yang terlalu tinggi akan menyebabkan umbi lebih mudah terserang penyakit (Cortbaoui, 1997). Kenyataan di lapangan, pembuatan bumbunan seringkali tidak seragam tergantung dari pekerja yang membuat bumbunan tersebut sehingga akan didapatkan tinggi bumbunan yang berbeda-beda.

Alternatif menangani masalah ini adalah dengan melakukan pembu mbunan dengan ketinggian yang ideal sejak awal penanaman. Pembumbunan dengan ketinggian yang ideal sejak awal penanaman diharapkan dapat mengurangi permasalahan yang terjadi dari pembumbunan yang tidak sesuai. Tujuan akhir dari pembumbunan ideal ini adalah mendapatkan produksi kentang yang tinggi.

Sentra produksi kentang di Indonesia salah satunya adalah Bandung, Jawa Barat. Iklim di daerah tersebut sangat sesuai untuk pertumbuhan dan perkembangan tanaman kentang sehingga banyak perusahaan kentang di daerah Bandung. Kegiatan penelitian bertujuan untuk mempelajari aspek pengelolaan budi daya kentang, yaitu untuk mengetahui pengaruh tinggi pembumbunan awal terhadap persentase tumbuh, tinggi tanaman, jumlah stolon per batang dan hasil panen tanaman kentang.

\section{BAHAN DAN METODE}

Kegiatan penelitian ini dilaksanakan dari 14 Februari 2011 sampai dengan 14 Juni 2011 di Bandung, Jawa Barat. Aspek umum yang diamati adalah seluruh kegiatan budi daya meliputi persiapan lahan, persiapan bibit, penanaman, pemeliharaan, panen, dan pascapanen. Data yang diamati yaitu jarak tanam, dosis pupuk, waktu dan aplikasi pemupukan, waktu dan cara panen, produksi kentang, dan lain-lain.

Aspek khusus yang diamati adalah pembumbunan awal saat tanam, untuk mengetahui pengaruh pembumbunan awal terhadap tanaman kentang. Tinggi pembu mbunan awal yaitu $10 \mathrm{~cm}$, $15 \mathrm{~cm}$ dan $20 \mathrm{~cm}$. Setiap perlakuan terdiri atas tiga ulangan sehingga didapatkan sembilan satuan percobaan. Setiap ulangan terdiri dari tiga baris tanaman. Setiap baris terdiri dari 20 bibit kentang. Total tanaman yaitu berju mlah 540 tanaman. Kegiatan dilakukan di Kebun Gambung -Ciwidey, Bandung Selatan. Peubah yang diamat i yaitu 
persentase tumbuh pada 14, 21, dan 28 HST (hari setelah tanam). Tinggi tanaman dilakukan pada tanaman contoh sebanyak 54 tanaman pada 28, 49, dan 56 HST, jumlah stolon per tanaman yang pengamatannya dilakukan hanya satu kali pada saat umur tanaman 56 HST. Tiga tanaman dari satu satuan percobaan dijadikan contoh (dicabut) untuk diamati ju mlah stolonnya. Pengamatan bobot umbi per tanaman dilakukan pada saat umur tanaman 97 HST yaitu saat panen.

\section{Kondisi Umum}

Ketinggian lokasi penelitian \pm 1 200-1 700 $\mathrm{m}$ dpl, suhu berkisar $12-28{ }^{0} \mathrm{C}$, curah hujan sebesar $2555 \mathrm{~mm}$ per tahun. Jenis tanah yang paling mendominasi di daerah yaitu tanah andosol dengan $\mathrm{pH}$ 5.0-6.5. Varietas kentang yang ditanam yaitu $75 \%$ Granola, 20\% Nadia, dan 5\% varietas lainnya. Total produksi kentang varietas Granola tahun 2007 yaitu 2158.89 ton, kemudian meningkat menjadi 2248.61 ton pada tahun 2008 . Terjadi penurunan angka produksi tahun 2009 menjadi 1687.65 ton.

\section{HASIL DAN PEMBAHASAN}

\section{Pengaruh Pembumbunan Terhadap Tanaman Kentang}

Pertumbuhan tanaman kentang terbagi menjadi tiga stadium yaitu stadium awal pertumbuhan, stadium pertumbuhan tertinggi, dan stadium penyempurnaan umbi (Sulaeman, 1997). Pertumbuhan awal tanaman sangat dipengaruhi oleh ketersediaan air, kesiapan tunas, dan gangguan hama dan penyakit tanaman. Perkembangan tunas yang prima akan membentuk organ tumbuh lainnya seperti batang, daun, stolon, dan umbi. Sejak bibit ditanam sampai muncul tunas ke permukaan tanah memerlukan waktu antara 10 sampai 14 HST.

Tabel 1. Rekapitulasi uji beda nyata terkecil pengaruh pembumbunan awal terhadap pertumbuhan vegetatif kentang

\begin{tabular}{|c|c|c|c|c|}
\hline \multirow[t]{2}{*}{ Peubah } & \multirow[t]{2}{*}{ Waktu (HST) } & \multicolumn{3}{|c|}{ Pembumbunan Awal $(\mathrm{cm})$} \\
\hline & & 10 & 15 & 20 \\
\hline \multirow[t]{3}{*}{ Persentase tumbuh (\%) } & 14 & 11.67 & 2.22 & 1.11 \\
\hline & 21 & $70.00 \mathrm{a}$ & $58.89 \mathrm{ab}$ & $39.40 \mathrm{~b}$ \\
\hline & 28 & 99.44 & 93.89 & 91.11 \\
\hline \multirow[t]{3}{*}{ Tinggi tanaman $(\mathrm{cm})$} & 28 & $16.25 \mathrm{a}$ & $12.44 \mathrm{~b}$ & $10.47 \mathrm{~b}$ \\
\hline & 49 & 58.45 & 58.77 & 56.22 \\
\hline & 56 & 61.68 & 64.01 & 61.39 \\
\hline Jumlah stolon/batang & 56 & 7.3 & 7.0 & 8.3 \\
\hline
\end{tabular}

Keterangan: Angka yang diikuti huruf yang tidak sama pada baris yang sama berbeda nyata pada taraf $5 \%$ atau $1 \%$

Tabel 1 menunjukkan bahwa perlakuan pembu mbunan awal dengan tinggi bumbunan 10 $\mathrm{cm}, 15 \mathrm{~cm}$, dan $20 \mathrm{~cm}$ berpengaruh nyata terhadap persentase tumbuh saat umur tanaman 21 HST. Tunas keluar menembus permukaan tanah lebih lama karena perlakuan pembumbunan tersebut dan umbi bibit yang digunakan berukuran kecil sehingga energi yang diperlukan untuk menembus permukaan tanah lebih besar dibandingkan dengan umbi bibit yang berukuran besar. Menurut Sofiari (2009) umbi yang berukuran besar memiliki cadangan makanan lebih banyak dibandingkan dengan umbi yang berukuran kecil sehingga energi yang dimiliki lebih besar.

Perlakuan pembumbunan berpengaruh sangat nyata terhadap tinggi tanaman saat 28 HST. Tinggi tanaman dihitung dari atas permukaan bumbunan hingga titik tumbuh tanaman. Tanaman akan lebih mudah menembus tinggi bumbunan yang tidak terlalu tinggi sehingga dapat lebih dahulu muncul ke atas permukaan tanah dan terus berkembang. Tanaman kentang yang sudah muncul ke permukaan akan tumbuh sangat cepat antara minggu kedua sampai minggu kelima (Asandhi et al., 1989).

Pertu mbuhan batang paling aktif kira-kira pada u mur tanaman 25 hari sampai 30 hari setelah tunas muncul ke permukaan tanah. Satu hari bisa bertambah panjang sekitar $3 \mathrm{~cm}$. Memasuki minggu ketujuh pertumbuhan tinggi tanaman akan relatif konstan.

Bersamaan dengan munculnya tunas ke permukaan tanah, tumbuh pula stolon. Jumlah stolon yang terbentuk ditentukan oleh beberapa faktor diantaranya kedalaman penanaman, ukuran umbi bibit, kelembaban tanah, dan nutrisi. Pemberian air yang cukup saat pembentukan stolon akan menstimulasi tumbuhnya stolon yang banyak. Sebaliknya, pemberian air yang kurang pada awal masa pertumbuhan berakibat rendahnya jumlah umbi yang dihasilkan (Sofiari, 2009). 
Tinggi bumbunan mempengaruhi ju mlah dan ukuran umbi, semakin tinggi bumbunan tanah maka stolon yang tertimbun semakin banyak sehingga persaingan makanan semakin ketat sehingga ukuran umbi akan kecil-kecil namun jumlahnya banyak (Ummah, 2010). Pertumbuhan stolon mencapai jumlah terbanyak sekitar umur tanaman 25 hari setelah tunas muncul ke permukaan.

Tabel 2. Rekapitulasi uji beda nyata terkecil pengaruh pembumbunan awal terhadap hasil panen kentang

\begin{tabular}{lcrcc}
\hline $\begin{array}{l}\text { Bobot Umbi } \\
\text { Kentang (kg) }\end{array}$ & $\begin{array}{c}\text { Waktu } \\
(\mathrm{HST})\end{array}$ & \multicolumn{3}{c}{$\begin{array}{c}\text { Pembumbunan Awal } \\
(\mathrm{cm})\end{array}$} \\
\cline { 3 - 5 } & & \multicolumn{1}{c}{10} & 15 & 20 \\
\hline ABC & 97 & 6.03 & 7.62 & 8.33 \\
Ares & 97 & 15.13 & 15.88 & 16.82 \\
Busuk & 97 & 1.37 & 1.48 & 1.95 \\
Total & 97 & 22.53 & 24.98 & 27.13 \\
\hline
\end{tabular}

Tabel 2 menunjukkan bahwa perlakuan pembumbunan tidak berpengaruh nyata terhadap bobot hasil panen. Jumlah umbi per tanaman berpengaruh terhadap bobot hasil. Semakin banyak umbi yang dihasilkan, semakin besar bobot umbi. Hal tersebut tidak mutlak karena apabila umbi yang dihasilkan berukuran kecil, maka bobotnya akan rendah. Hasil yang tinggi menjadi kurang berarti apabila umbi yang dihasilkan berukuran kecil, karena umbi berukuran kecil memiliki harga jual yang rendah untuk kentang konsumsi. Varietas yang mampu menghasilkan umbi berukuran besar, tetapi jumlahnya sedikit juga bermasalah dalam pengadaan pembibitan.

Tabel 3 menunjukkan bahwa kondisi tanaman di Kebun Gambung paling banyak terserang penyakit dibandingkan kebun yang lain. Tanaman menjadi layu dan saat panen banyak sekali umbi yang busuk. Hal ini terjadi karena curah hujan sangat tinggi sehingga keadaan tanah menjadi lembab.

Tabel 3. Persentase serangan penyakit di kebun

\begin{tabular}{lc}
\hline & Serangan Layu Bakteri dan Busuk \\
Kebun & Daun \\
\hline Gambung & $>40 \%$ \\
Ciarileu & $<10 \%$ \\
Pasir Angin & $<10 \%$ \\
Kiara Jeuntas & $<10 \%$ \\
\hline
\end{tabular}

Tanah yang lembab tidak hanya merusak pertumbuhan akar, tetapi juga merusak kualitas tunas, memperbanyak tanaman yang terjangkit penyakit, sehingga menjadi penyebab kebusukan kentang.

\section{Produktivitas Kebun}

Kebun memiliki produktivitas yang berbeda-beda dipengaruhi beberapa faktor yaitu kondisi lahan yang meliputi jenis tanah, kesuburan tanah, dan ketinggian tempat. Faktor iklim meliputi suhu udara, curah hujan, dan kelembaban. Faktor teknis budi daya sangat penting karena mampu memanipulasi lahan yang kurang subur menjadi lahan yang subur. Faktor lainnya yaitu varietas dan mutu bibit, varietas unggul yang resisten terhadap hama dan penyakit menentukan keberhasilan usaha tani kentang. Mutu bibit meliputi ukuran dan kesehatan bibit. Faktor yang terakhir yaitu serangan hama dan penyakit, serangannya dapat mengakibatkan bagian-bagian tanaman menjadi busuk atau mati.

Tabel 4. Produktivitas tiap kebun berdasarkan persamaan generasi kentang Granola G3

\begin{tabular}{lccccc}
\hline \multirow{2}{*}{ Kebun } & Luas Lahan (ha) & \multicolumn{2}{c}{ Total Panen Kentang (kg) } & \multirow{2}{*}{ Produktivitas (ton ha $^{-1}$ ) } \\
\cline { 2 - 4 } & & Kentang Konsumsi & Bakal Bibit & BS & \\
\hline Ciarileu & 2 & 17442 & 15048 & 699 & 16.59 \\
Pasir Angin & 3 & 16302 & 37126 & 813 & 18.08 \\
Kiara Jeuntas & 2 & 13235 & 25550 & 777.4 & 19.78 \\
Gambung & 2,5 & 22420 & 20368 & 1240 & 17.61 \\
\hline
\end{tabular}

Tabel 4 menunjukkan bahwa Kebun Kiara Jeuntas memiliki produktivitas tertinggi di antara kebun yang lain. Hal ini disebabkan oleh teknik budi daya yang dilaksanakan sudah baik seperti penggunaan bibit yang berkualitas baik, pelaksanaan pemeliharaan tepat waktu, penggunaan pupuk dan pestisida yang tepat. Kebun yang memiliki produktivitas paling rendah yaitu Kebun Ciarileu. Hal ini disebabkan oleh penggunaan bibit yang sudah memiliki penyakit atau seed borne disease sehingga produktivitas kentang di Kebun Ciarileu menjadi rendah. Sistem irigasi yang kurang terkontrol menjadi salah satu penyebab rendahnya produksi. Hal tersebut terlihat dari banyaknya umb i kentang yang busuk akibat tanah yang terlalu lembab karena genangan air di kebun.

Keempat kebun di atas memiliki produktivitas yang lebih tinggi dibandingkan dengan produktivitas nasional tahun 2009 yaitu sebesar 16.51ton $\mathrm{ha}^{-1}$. Kebun Ciarileu dengan produktivitas terendah dari empat kebun di atas 
masih lebih tinggi produktivitasnya. Masalah produktivitas kentang yang adalah serangan penyakit yang sangat tinggi akibat dari cuaca yang ekstrim yaitu hujan yang terus-menerus. Penyakit yang merugikan bagi pertanaman diantaranya layu bakteri (Ralstoniasolanacearum), busuk daun (Phytopthora infestans), dan penyakit kudis (Streptomyces scabies). Masalah budi daya yang sering terjadi yaitu pada saat penyiangan gulma yang tidak bersih, masih banyak akar dan umbi gulma yang tertinggal sehingga gulma dapat tumbuh kembali. Keterlambatan dalam melakukan pembumbunan dan pemupukan atau pembumbunan yang hanya sekali. Alternatif untuk kembali men ingkatkan produktivitas kentang adalah dengan rotasi tanaman yang bukan famili dari Solanaceae. Tanaman yang digunakan sebagai rotasi adalah wortel, jagung, kubis dan rumput gajah. Rotasi ini digunakan untuk memutus rantai penyakit yang ada di lapangan. Tanaman rotasi ini juga dapat menutupi kerugian dari pertanaman kentang yang kurang berhasil.

\section{KESIMPULAN}

Perlakuan pembumbunan awal $10 \mathrm{~cm}, 15$ $\mathrm{cm}$, dan $20 \mathrm{~cm}$ berpengaruh nyata terhadap persentase tumbuh pada 21 HST dan berpengaruh sangat nyata terhadap tinggi tanaman pada 28 HST. Perlakuan tidak berpengaruh nyata terhadap jumlah stolon per batang dan bobot umbi hasil panen. Produktivitas rata-rata umbi kentang Granola G3-G4 yaitu 18.01 ton ha ${ }^{-1}$, lebih besar dari produktivitas nasional tahun 2009 sebesar 16.51 ton $\mathrm{ha}^{-1}$. Hal ini menunjukkan kegiatan budi daya kentang sudah dilakukan dengan cukup baik.

\section{DAFTAR PUSTAKA}

Asandhi, A.A., S. Sastrosiswojo, Suhardi, Z. Abidin, dan Subhan. 1989. Kentang Edisi 2. Bandung (ID): Balai Penelit ian Tanaman Sayuran.

[BPS] Badan Pusat Statistik. 2010. Produksi Sayuran Nasional [Internet]. [diunduh 2010 Okt 02]. Tersedia pada: http://www.bps.go.id/.

Cortbaoui, R. 1997. Menanam Kentang, Edisi Buletin. Priatna, E., penerjemah. Bandung (ID): Balai Penelitian Tanaman Sayuran. Terjemah dari: Planting Potato, Technical Information Buletin.
Rubatzky, V.E., Yamaguchi, M. 1998. Sayuran Dunia 1 : Prinsip, Produksi dan Gizi. Herison, C., penerjemah. Bandung (ID): Institut Teknologi Bandung. Terjemah dari: World Vegetable 1 : Principal, Production and Nutrition.

Samadi, B. 2007. Kentang dan Analisis Usaha Tani. Yogyakarta (ID): Kanisius.

Setiadi, Nurulhuda, S.F. 2008. Kentang : Varietas dan Pembudidayaan. Jakarta (ID): Penebar Swadaya.

Sofiari, E. 2009. Daya hasil beberapa klon kentang di Garut dan Banjarnegara. J.Hort. 19 (2): 148-154.

Sulaeman, E.R., W. Wintarasa, Sumarna, N. 1997. Perbanyakan Bib it Kentang Berkualitas Tinggi Bebas Penyakit. Bandung (ID): Balai Benih Induk.

Ummah, K. 2010. Produksi Bibit Kentang (Solanum tuberosum L.) di Hikmah Farm, Pangalengan, Bandung, Jawa Barat [skripsi]. Bogor (ID): Institut Pertanian Bogor.

Williams, C.N., Uzo, J. O., Peregrine, W. T. H. 1993. Produksi Sayuran Daerah Tropika. Ronoprawiro, S., penerjemah. Yogyakarta (ID): Gad jah Mada University Press. Terjemah dari: Vegetable Production in the Tropics. 